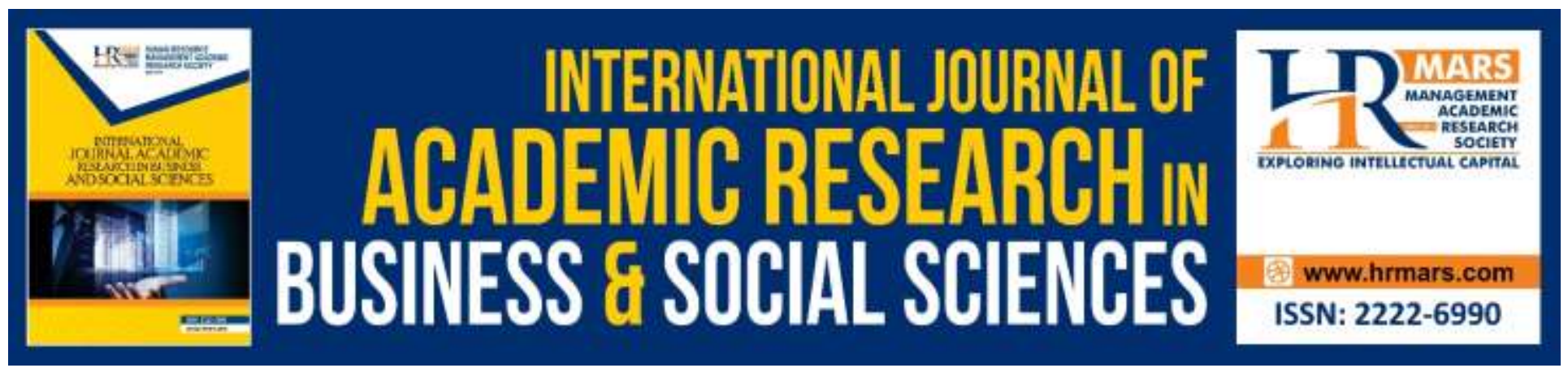

\title{
A Struggle against Colonizer: The Commitment of Ashab Jawi
}

Muhd Imran Abd Razak, Rahimin Affandi Abdul Rahim, Mohd Anuar Ramli, Nurul Hidayah Abd Aziz, Paiz Hassan, Muhammad Yusri Yusof @Salleh

To Link this Article: http://dx.doi.org/10.6007/IJARBSS/v9-i7/6146

DOI: $10.6007 /$ IJARBSS/v9-i7/6146

Received: 13 May 2019, Revised: 12 June 2019, Accepted: 01 July 2019

Published Online: 29 July 2019

In-Text Citation: (Razak et al., 2019)

To Cite this Article: Razak, M. I. A., Rahim, R. A. A., Ramli, M. A., Aziz, N. H. A., Hassan, P., \& @Salleh, M. Y. Y. (2019). A Struggle against Colonizer: The Commitment of Ashab Jawi. International Journal of Academic Research in Business and Social Sciences, 9(7), 527-549.

Copyright: (C) 2019 The Author(s)

Published by Human Resource Management Academic Research Society (www.hrmars.com)

This article is published under the Creative Commons Attribution (CC BY 4.0) license. Anyone may reproduce, distribute, translate and create derivative works of this article (for both commercial and non-commercial purposes), subject to full attribution to the original publication and authors. The full terms of this license may be seen

at: http://creativecommons.org/licences/by/4.0/legalcode

Vol. 9, No. 7, 2019, Pg. 527 - 549

http://hrmars.com/index.php/pages/detail/IJARBSS

JOURNAL HOMEPAGE

Full Terms \& Conditions of access and use can be found at http://hrmars.com/index.php/pages/detail/publication-ethics 


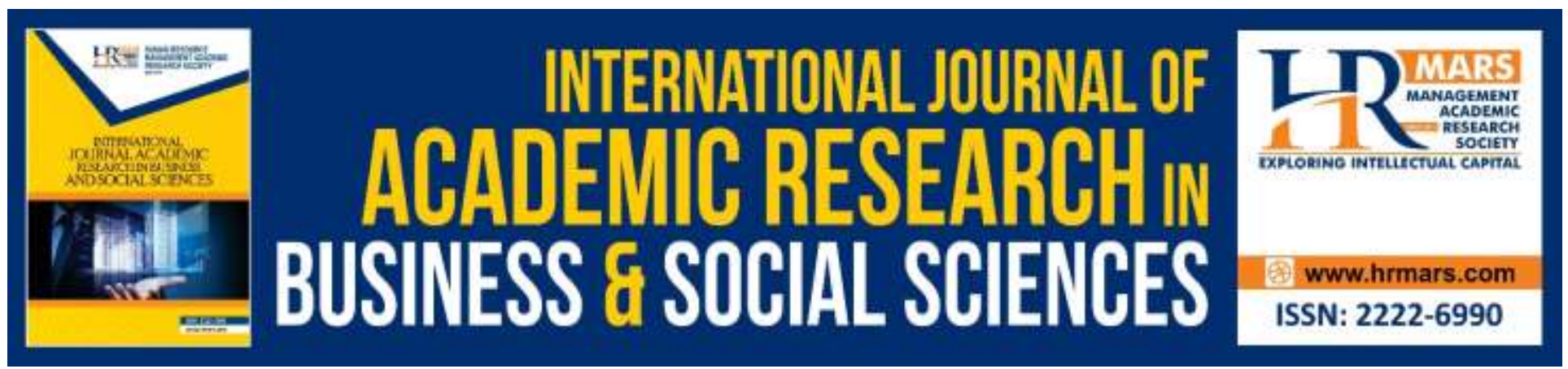

\title{
A Struggle against Colonizer: The Commitment of Ashab Jawi
}

\author{
Muhd Imran Abd Razak (Ph.D) ${ }^{1}$, Rahimin Affandi Abdul Rahim \\ $(\text { Ph.D) })^{2}$, Mohd Anuar Ramli (Ph.D) ${ }^{3}$, Nurul Hidayah Abd Aziz ${ }^{4}$, Paiz \\ Hassan $^{5}$, Muhammad Yusri Yusof @Salleh ${ }^{6}$
}

${ }^{1}$ Senior Lecturer, Academy of Contemporary Islamic Studies, MARA University of Technology, Perak, Malaysia, ${ }^{2}$ Associate Professor, Department of Fiqh and Usul, Academy of Islamic Studies, University of Malaya, Kuala Lumpur, Malaysia

\begin{abstract}
Differ to the feudal class who adhere to colonists, the latter was challenged by the Muslim scholars and Ashab Jawi who responsible to disperse the spirit of jihad in the Malay world. They are the figures who decide not to submit to the demand of being pro-colonist. Indeed, they the figures masterminded the struggle of jihad proven thru historical accounts written by the colonists. The study then aimed to analyze the contribution of Ashab Jawi pertaining to their engagement in jihad and the significance of their struggle against the colonists in Malaya. Hence, the study applies qualitative of inductive and deductive analysis methods referring to Jawi books as well as Malay disposition which also observed and writes by orientalists. The finding shows Ashab Jawi has penetrated the elements of jihad in their writings indeed has reminded the importance of preserving faith and restoring Islamic administration. Although the colonists attempt to hinder the elements of jihad from various approaches, the struggle nevertheless, successfully influence the Muslim community, the later scholars and the educational system.
\end{abstract}

Keywords: Islamic Scholars, Malay World, Ashab Jawi, Jawi Books.

\section{Introduction}

To comprehend Malaya nationalism is to struggle Malaya's religion i.e. Islam. Also, the great influence of Pan-Islamism, Acheh and Ottoman diplomacy, and brotherhood of Muslim scholar such as Sheikh Muhammad al-Falimbani from Palembang (Indonesia), Sheikh Muhammad Zain al-Ashi from Aceh (Indonesia), and Sheikh Muhammad al-Fathani from Patani (Thailand) has driven in the elements of jihad till the educational system although the colonists made moves to demur the elements of jihad in Malay world thru feudal predominance. 
Jihad stands with criteria. Some criteria of jihad as suggested by Muslim scholars are explained in this study in order to rectify the falsification of jihad referring to virulent physical warfare, spearheaded by Muslim believers. Islam is aware of others' belief however, jihad is portrayed as an act of maintaining religion over non-Muslim or infidels who assault or have different belief other than Islamic teaching.

Notwithstanding, killing is certainly prohibited in Islam. In fact, this study performed to rectify the understanding of jihad, methods applied by the Muslim scholars to restore the elements of jihad as well as the position of Ashab Jawi and their struggles. It thus inculcates the soul of jihad i.e. religious teaching as well as preserves Islam in the Malay world lasting over generations.

We should imitate the practice of Indonesian government who awards warrior status, to every figure involved in fighting for Indonesia's independence. It is an honored to the family members and more importantly, this election will remain open to all. It is also, does not belongs merely to the dominant figure (feudal) sponsored by the former colonists, however should comprise the unsung heroes, such as scholars and leftists. On this basis, the study attempts to reward the aforementioned mujahideen through intellectual exposure that will be learned by next generation. It is, indeed an act to appreciate the early mujahid as well as to prolong their rewards (jariah).

\section{Jawi Clerics as Real Malay Mujahids}

The main premise of the study is jawi clerics as the true mujahideen who struggle for Islamic Malay nationalism. This is based on historical evidence and opinion of colonial scholars. They explain that the Ashab Jawi scholar is a real figure who blows and fights the anti-colonial spirit in the Malay world. The scholarly figures is the early Malay clerics (17-20th century) who directly upraising the spirit of jihad in the Malay World. Among them are Syeikh Daud Pattani, Yusuf Makasari, Abdul Samad Palimbani, Tokku Paloh, Tok Janggut and so on.

\section{Scenario of World Political Order During Crusade Era}

The author offers edu-maqasid analytical approach while reviewing extremism in the context of At the global age i.e. in the post-crusade era, Islamic scholars were aware of the idealism of Dar-Islam and Dar-Harbi (Razak, 2019). Meanwhile, the era shows that Muslims dominate the world's strategic elements in the form of international trade. Indeed, Arabs are more precarious than European in terms of trade, between east and west (Reid, 1990). Thus, the former has better understanding regarding the macro - political trade system is being carried out (Tahtooh, 1987). This was, then constructed by Islamic political scholars in Islamic political theory. From the beginning, western traders had to rely on information from Arabs in order to know the realities of Malay world, including its populations (Braddel, 1851).

As a result, the two nations are aware of there are two blocs of world powers that based on religious and military power Muslim and non-Muslim (represented by Portuguese / Christians who are hostile to Muslim bloc). Among the Islamic blocs, there are blocs of; (i) Turkey who holds the 
caliphate status of Islam and military power (Peacock, 2015); (ii) Mughal and Saljuk who also have strong military power; (iii) Middle East is the center of Islamic scholarship and (iv) Malay blocs (peripheral) which require auspices from blocs i, ii and iii (Shaharel, 1997). For example, the issue of Portuguese colonialism in Melaka was widely discussed by Muslim leaders during the pilgrimage season in Mecca.

In strategic terms, all these Islamic blocs understand the importance of Muslim ummah which involved;

First, the importance of controlling trade routes between the Indian Ocean and the Red Sea. More importantly, the Malay was well aware of the potential of the raw materials that the world community needed at that time. This is confirmed by the fact that the Malay world became the main center visited by foreign ships to get the raw materials required by the world community. Many European ships have reportedly been trading in the Malay World, especially in Aceh (Hannan, 2014). The West acknowledged as commented by the Portuguese administrators in Asia, Lamos (1585); if Aceh and the Malay world succeed in colonization, the Portuguese will dominate world trade routes;

"Sumatra is such a wonderful thing, and contains such great riches, that I dare to affirm (according to what many experienced old men related, whom I overheard when they were conversing with the viceroy of India) that it could well be considered as the equal of England, of which the scriptures speak so highly." Tegasnya lagi, "The conquest of Atjeh would give the Spanish-Portuguese Crown the economic resourses where with to destroy not only 'the Heresiarchs and their followers', but to recover all Christian territory lost to the Muslims (including Jerusalem), and to overthrow the Ottoman Empire." (Boxer, 1969).

Second, the importance of providing military assistance to fellow Islamic blocs and the agreement of spreading and publishing Islamic works from all these blocs. History records how Islamic works of various blocs are disseminated and published in certain areas of these blocs; Istanbul, Bombay, Malay World, Egypt and Mecca (Sidin, 2000). At present, the power of Aceh and Turkey has indeed played a logistical effort in championing the political agenda of Islam.

\section{The Roles of Aceh Government}

Aceh is a great Islamic power that is capable of hindering the development of Christianity which is the main agenda of the Portuguese colonizers. It is increasingly apparent after the fall of Malacca to Portuguese. The Acehnese government in the Western scholarship is described as a violent government and shedding blood of different religions (Hurgronje, 1985). It was noted by Portuguese historians, how the Aceh government refused to have a good communicate when dealing with a Portuguese trader. The Portuguese historical record explains that the Portuguese tried several times to avoid warfare, as their goal was to trade with other governments in the Malay World.

They also exaggerated over the greatness of Portuguese forces compared to Acehnese army. The Aceh kingdom is said striving to monopolize the spices in the Malay World by attacking and destroying black pepper fields in other areas. Aceh was also said to have attacked other regions as to 
expand its power and was followed by the base of bringing prisoners of war to Aceh, to serve as slaves and concubines (Smith, 2007). These servants are said to have been mistreated by the people of Aceh. The people of Aceh are said to have many slaves and concubines for the interests of Acehnese leaders (Mitrasing, 2011). Western scholars also through foreign travelers note, have described Aceh has practicing hudud law system which is very cruel and inhumane (Jajat, 2014).

Should Aceh not take this proactive step, it is likely that the Malay community will consider the development of Christianity as normal. Indeed, the Portuguese colonists were recorded in history as a nation that prefers to use violence against Muslims. In addition, they often use the method of deception in the dissemination of Christianity. The efforts by Aceh has proved to have succeeded in preventing the development of Christianity and retaining the dominance of Islam in the Malay World (Tisdall, 1916).

2011);

After in-depth analysis, Aceh struggles was based on a number of the key reasons (Dien,

1. The attack on other states is to penalize them concerning their corroboration to Portuguese. The suppression of oppressed prisoners is incorrect, because many of these prisoners of war are accepted as the most important people in Aceh, for example King Iskandar Thani, Princess Kamelia and Tun Seri Lanang. King Iskandar Thani was originally a prince of Pahang, who was captured and appointed to succeed King Iskandar Muda. Similar to Princess Kamelia, the prisoners from Pahang have become the legitimate King Iskandar Muda's wife. He was later responsible for as palace advisor then formed the national meeting body to hear the people. Its significance has proven in the Hadith Maja, used in Aceh; a formula on how state governance needs to be practice. The Acehnese community is a cosmopolitan society and its impact is still visible.

2. The Political Discipline Strategy (Politik Membesan) practiced by Aceh can ensure the political power of the Malay World can be carried out in a systematic form in accordance with the reality of the Malay World. The Politik Membesan practiced by the Aceh government is full of wisdom in forming a family based on the spirit of Islamic brotherhood. What has been done through this tactic is that Aceh is trying to marry the king and the king's descendants from Pahang, Kedah and Perak; as to strengthen relations on the basis of Islamic brotherhood with the royal family of the Malay states. Not only will the relationship be established, but this tactic will also gain sympathy and support from the civil society, that loyal to the royal family. In the Malay world, the tactics of spreading Islam have been done through the institution of marriage. It is more natural as marriage will create and combine two different families for greater purpose, elevating Islam.

Aceh establishes the Islamic brotherhood of Muslims among the Malays. It is like setting up a conducive site for Islamic development. The Acehnese effort to combat the Portuguese colonial power and to close up relations with the Malay states has succeeded in establishing the bond of the Malay Islamic Brotherhood (The Allied Malay Nationalism) based on the relationship between Aceh kingdom, Minangkabau, Malay Peninsular and Banjarmasin. Although these locations are quite large and distant, efforts to create unity are always in its place (Dien, 2011). 
The Aceh exertion is considered to be a defender that protects the Muslim ummah from the invasion of the disbelievers. It is also supported by the use of Malay as Lingua Franca among the Malay kingdom and it became the most important tool for the development of science and intellectuals in the 17th century (Amirul, 2004). Aceh has a strong relationship with the Ottoman government, being an assistant against the colonial power and as patron ship carrying the Malay Haj pilgrims (Ermy, 2014). As a result, as noted in Abdullah Munsyi's note, the condition of the Malay Haj pilgrim that was once full of difficulties had improved and was better (Munsyi, 1981). The basis of Aceh-Ottoman relationship contributes to the existence of the Javanese community in Haramayn (Malay scholars and students who deepen and spread the teachings of Islam) (Azra, 2015). The jawi community then contributed to the existence of intellectual linkages between the Malay world and Haramyn. It has accelerated the empowerment of the Islamic world-view and intellectuality in the Malay world, in unprecedented form.

\section{Confederation of Aceh and Turkey: Pan-Islamisme}

Based on the awareness of Islamic brotherhood, pan-Islamism has been the greatest benefit to the development of Islam in the Malay World. Before the idea of pan-Islamism was fully introduced by Jamaluddin Afghani in the early 19th century, the ideology had been practiced by Aceh and the Ottoman Empire since the 16th century (Itzkowitz, 1972). At the time of Ottoman Empire fighting for pan-Islamism in the West, the Acehnese had first recognized the idea of this unity which was followed by various attempts to establish diplomatic relations with the Ottoman powers. In the fight against western power in the Malay World, Aceh considers it is necessary to strengthen its government as the unifying power of the Muslim ummah in the Malay World and subsequently need to establish a relationship with Islamic power in the west (Reid, 1969).

The Pan-Islamism (Ferguson, 2008) concept is considered a practical model of unity between the Islamic ummah in two different continents (east and west) that existed from the beginning. Among the essence of this idea (Ozay, 2011);

1. The worldwide Muslim ummah has to recognize and convey the Ottomans as the khalifah of Muslims. It is a source of unity and authority for other Muslim countries. On that basis, Muslims worldwide (Middle East, west and east) need to be united in accordance with the will and concept of the ummah.

2. The Muslim ummah should equally support if other Muslims are in trouble.

3. The Muslim ummah in different areas must ensure the military power and maintain the domination of Muslims in world trade involving the Indian Ocean and the Red Sea.

4. Diplomatic relations between the great powers of the west (Ottoman) have always been reinforced.

5. The utmost, where Ottoman powers should play the role of safeguarding the sovereignty and welfare of the Muslim world, harboring Haramyn, ensuring the safety of merchant vessels and Islamic pilgrims around the Indian Ocean and being the cause of authority for other Muslim governments (Ozay, 2013). 
INTERNATIONAL JOURNAL OF ACADEMIC RESEARCH IN BUSINESS AND SOCIAL SCIENCES Vol. 9, No. 7, July, 2019, E-ISSN: 2222-6990 @ 2019 HRMARS

The history of diplomatic relations between Aceh and the Ottoman powers was initiated by the Sultan Muhayyat Shah who had established relations with pan-Islamism idealism. Chronologically, this relationship goes mutually in some form;

First, the Ottoman authorities sent fleets and military specialists to assist Muslim traders and the Acehnese government from Portuguese's interference along the Indian Ocean and the Red Sea (Azra, 2004). As a result, merchant trading activity of the Malay and Indian regions with the Mediterranean area has been successfully enhanced.

1. In 1537, Sultan Sulaiman (1520-1566) ordered his governor in Egypt, Sulaiman Pasha prepared the army to destroy the Portuguese fleet in the Indian Ocean. This Ottoman fleet reaches Aceh to help Acehnese fight against Aru, Batak and Portuguese (Reid, 2004).

2. The Ottoman authorities have dispatched military specialists and weapons and artillery experts to Aceh. In 1562, Aceh sent delegation to Istanbul to seek help and, in 1564, the Ottoman aid arrived to Aceh. In 1566, the Acehnese delegation (Sultan Aluadin Kahar) arrived in Turkey informing and express thanks the Turkish aid of 8 Turkish artillery experts. Sultan Alaudin Kahar also sought assistance to house merchants and pilgrims through the Indian Ocean (Rahman, 1986).

3. In 1567, Sultan Selim 11 expanded the Turkish fleet in the Indian Ocean, as many as 15 Turkish fleets were directed to Aceh.

Secondly, the Turkish Ottoman aid has boosted the spirit of the Islamic kingdom in the Malay World fighting the Portuguese;

1. In 1568, 1570 and 1573, Aceh used the Turkish military equipment against the Portuguese in Melaka.

2. In the same years, Aceh had collided with the Islamic sultan in Bijapur, Colconda, Bidar and Ahmad nagar invading the Portuguese in Goa (Smith, 1958).

3. In 1570s, Sultan Bab Ullah in Ternate, with the help of the Sultanate of Demak had succeeded in expelling the Portuguese from the Maluku archipelago (Restu, 1999).

4. During 16th century, the Islamic kingdom of Button and Minangkabau was successfully founded on the aid of Ottoman authorities. It was reported that Turkish descent became the founder of the two sultanates (Marsden, 1783).

5. In 1855, Sultan Taha Safiuddin of Jambi and Palembang rulers demanded Turkey to declare Jambi and Palembang regions as under Turkey settlement.

Third, relations with Turkey have encouraged the migration of Arabs to the Malay World. In the mid-1840's, thousands of Arabs from Hadharalmaut migrated to the Malay World, most of whom were Habib's well-known as preachers who led the missionary efforts in the Malay World. Moreover, the Arabs have formed an association that fully supports Turkey (Erny, 2012).

Fourthly, this relationship has succeeded in discourage the power of the western colonists from tyranny of Muslims in the Malay World. There are some proven facts, among them;

1. The Portuguese general secretary in Goa, Jorange De Lemos in 1585, reported to the Lisbon parties of his concern for the close connection between Aceh and the Ottoman powers in the Indian Ocean and the Red Sea, where the merchant ship of Aceh was justified to bear the Ottoman flag. 
He then sought help from Lisbon to strengthen the armies of the Portuguese army in the east (Azra, 2004).

2. The Turks have appointed Turkish counselors in the Malay World. Up to 1904, a total of 8 counselors were appointed. It serves to accept the abuse of Dutch and British colonialist complaints, distributing the official Quran and publishing Islamic works. The counselor also serves to report the situation of Muslims in the Malay World to Arabic newspapers in the Middle East. Among them are Akhbar Al-Malumat in Istanbul and Thamarat Al-Funun in Beirut (Kayadibi, 2011). The Dutch and British colonizers have undoubtedly favored the Ottoman power base which received full support from various Islamic NGOs in the Malay World (Hurgronje, 1994).

\section{Intellectual Dimension in the Struggle of Jihad}

It is obviously, early Muslim scholars and missionaries have come to the terms of international scenario between international political opposition of the two Islamic and non-Muslim Islamic blocs. The Malay scholar understands that the development of material and intellectual civilization of Muslims needs to depend on the concept of Jahada. The word of jahad, when apply in science, it will produce ijtihad; an Islamic science for community application. While the word jahada in the field of politics will be interpreted as the concept of jihad. It is an effort to defend Islamic civilization from the threat of internal and external enemies. To early jawi clerics, they understand, the inner enemy in the form of human desire that needs to be prevent thru tasawwuf knowledge. The external enemy is a pagan power that will destroy Muslims.

For Malay scholars in the second and third generation, the legacies left by the early missionaries need to be defended. It is;

1. The Islamic Malay government system that implements Islamic rule. This Islamic government is the foundation of Islamic law that can be implemented.

2. The application of the knowledge culture includes the institutions of Islamic studies and the production of jawi books to support the Islamic governance system. A material civilization that is not supported by a culture of knowledge, such as a beautiful palace built with sand, visibly will be easily destroyed when it comes to modification.

3. Understanding the true enemy of Muslims; the infidel's power that would undermine Islamic civilization. Through the affirmation of the Quran that Christians will surely become an eternal enemy of Islam. This is proven by a series of crusades between Islam and Christianity. We can take pride in the early missionaries in the Malay world successfully instilled that Christian political power is the immortal enemy of Muslims. It is recognized by the Christian missionaries who assert that the Malay World is an obscure area for Christianity.

According to Daud (2009), there are three great strategies made by the Malay scholars to strengthen the struggle of jihad.

\section{Hajj Institution as a Subject Apprentices of Islamic Struggle}

Basically, jihadist struggle in the Malay World is related to the intellectual network that occurs in the Middle East, especially Mecca and Medina (the two Holy Places). The Malay scholars have played an 
important role in blowing the spirit of jihad in the struggle against the Malay colonialists (Bruinessen, 1992). Issues that occur among Muslims around the world such as colonization and tyranny are shared and discussed in Mecca and Medina. This condition not only achieves sympathy among pilgrims, but also achieves spiritual and material support. For example, the issue of discussion of Portuguese colonialism in Melaka in 1511, has influenced the struggle to defend Aceh from being colonized by the Dutch (Amirul, 1992).

This situation is actually influenced by the presence of well-known and active scholars in Makkah around the 17th century, in addition to actively producing apprentice scholars who inherited knowledge tradition. They also succeeded in injecting the spirit of jihad among the scholars who came from Malaya. Among the scholars included Sheikh Muhammad al-Falimbani from Palembang (Indonesia), Sheikh Muhammad Zain al-Ashi from Aceh (Indonesia), and Sheikh Muhammad alFathani from Patani (Thailand). They have formed influential novices in the Malay World such as Sheikh Muhammad Arsyad al-Banjari, Sheikh Yusuf al-Maqassari (Makassar), Syeikh Abdul Wahab Bugis, Sheikh Muhammad Nafis al-Banjari, Syeikh Muhammad Ali Aceh and Syeikh Daud al-Fathani (Hasanuddin, 2009).

The apprentices has proved to be an important role and active in the fight against the colonialists in the 18th century. Such figures include Syeikh Abdul Samad al-Falimbani and Sheikh Daud al-Fathani. These two men were involved in the war against the Siamese colonists in Patani. The open-ended opposition has produced apprentice of clerics who are also fighters in various areas of the Malay World. Among them are Syeikh Wan Hasan Besut, Syeikh Muhammad Bendang Daya, Syeikh Abdul Halim Kelantan, Syeikh Abdul Qadir Mustafa Bendang Daya, Tuanku Tambusai minangkabau and Raja Ahmad Raja Ali Riau who are Syeikh Daud al-Fathani's apprentice (Sarif \& Faisal, 2014).

Knowledge networks and subsequent struggles move to the later generations which can be regarded as the "grandson" of the pupil, Sheikh Ahmad bin Muhammad Zain al-Fathani (Adib \& Zaini, 2011) who are references and important people in the history of the rise of the struggle against the Malay colonialists. On that basis, Mecca has become the center of the movement's struggle for the independence of Muslims. As a result, these graduate scholars have been directly involved in the colonial opposition in their homeland. Among the real examples are war in Padri, Banten, Makasar, Pattani and Palembang.

\section{The Production of Jihad Writings for Malay Community}

\section{i. The role of Syeikh Daud Pattani}

He can be regarded as a jihadist trigger in the Malay World by producing jawi books that directly explain the obligations of jihad against the colonialists to Muslims. The discussion of the issue of jihad is fragmented in three books that are produced; (1) Lum'ul Fawa'id, (2) the book Tuhfatul Gharibin and (3) the book Munyat Muslli (Azra, 2005).

After analyzing the contents of these three books, we can summarize into: 
First, though Daud Pattani is far from the Middle East but the spirit of patriotism is still strong. He does not want to lose contact with the fate of his community, Pattani.

Second, the spirit of jihad based on the assertion of the Quran, Sunnah and the view of the scholars to the Islamic fighters in Pattani. He considers jihad in the Malay world is not in vain but they will be rewarded in herenow and hereafter which promised by Allah. Accordingly, it encourages and strives to raise the spirit of jihad for the Muslim community of Pattani to proceed jihad because it is regarded as a fardu ain in order to maintain the Islamic government to remain in power. Without jihad, it would be futile to practice religion rather than the aspect of akidah, sufi and shariah. In short, Islam is not simply to be understood but also to be proven by the jihad that will sacrifice the life. He can even achieve martyrdom status of a very high status in God's sight. He deliberately used this jihad call in general, for all the populations of the Malay World for acknowledging the fate of Muslims oppressed by western colonists not only in Pattani, but also in Aceh, Malaya, the Philippines and Sumatra (Ismail, 2011).

Third, explains the goals and laws of jihad. The goal is to ensure that the Islamic government can be maintained, because without the government it is certain that the practice of Islam is not possible. This Islamic government is required to carry out the implementation of shariah and enable the Islamic profession to grow rapidly as well as create a unity of the Muslim ummah. On this basis, Ibn Khaldun asserted that the nature of racism is the gift of God to every human being. It is like the genitalia that God provides for all humans. If the genitals are used for illicit purposes it goes wrong, and if used for the right purposes it can be the basis of self-strength. Likewise, if the human being was born without genitalia, it would be considered imperfect. We rationally admit that if a person is born without a genitals it would be considered incomplete. This is because with the help of this genitals, many benefits will be produced for human interest. Thus, the logic of this genitals, whether or not, is not a big problem but must be subject to obedience to God's law (Saleh, 2004).

For Dr. Burhanuddin Helmi, the spirit of patriotism has a symbiotic relationship with Islam. There are four elements that relate to the spirit of love to his race namely faith, self, race and culture. Faith stands over self. Self-standing on nations and nations must stand on the motherland. As human beings need freedom and independence to live and qualify for the Islamic taklif, then the independence of the nation and motherland, is necessary to ensure that religion can be upheld on earth (Kamaruddin, 2000). The jihad is mandatory for a scholars or a Muslim leader to proclaim it. It becomes a fardu ain which is obligatory to all Muslim societies except for certain groups which are excluded such as children, women, sick and slaves. Religious students and active Sufi members must engage in jihad.

There are certain conditions of jihad, as Muslims cannot begin to oppress the non-Muslims. Jihad is only permitted when Islam and the rights of Muslims are invaded. Other conditions are necessary to comply with the requirements of jihad set by the scholars. Most importantly, in order to ensure that the jihad calls for the attention of the readers, Daud Pattani has made an argument 
on the importance of jihad whether fardu ain or kifayah based on a large number of Quranic verses, sunnah and scholars' views.

Fourth, to awaken the Muslim community in Malay World regarding the fate of Muslims in Pattani that oppressed by Siamese government. This is because, he knows the Muslims in the Malay World are in the comfort zone, who forget about the fate of the Pattani's. He seems to have been able to anticipate the attitude of Muslims in other places who are reluctant to care for the fate of Pattani's Muslims as it was in the latter days. Muslims in other areas are obliged to take an attitude of concern and help the struggle of the Muslim ummah. As a major urge, he narrates the advantages of those who strive in the way of Allah compared to ordinary people.

All of these works included the jihad and political doctrines (in the sense of colonization and impetus to defend the country) in one of its discussions and applied in the study of the Malay World. This means that in the pondok study system in the Malay World, the issue of jihad is one of the mandatory headlines that Muslims need to learn. The doctrine of jihad is also one of the subjects of the study which is the subject of fiqh, indeed it is the first stage of Islamization process in the Malay World (Abd Rahim, 2017). Hence, it is argued that the doctrine of jihad is also in line with the Islamization process in the Malay World. The doctrine of jihad by Syeikh Daud al-Fathani is described in the book named Bughyah al-Tullab which includes the following statement:

"And partial of them, the sabil war for kuffar (infidels), it is mandatory for the Imams to carry duty (struggle) on their land which is fardu kifayah with ijmak (consensus). Or the deputy Imams went with the army because of their war." Or revamped the city between them and their land, and strengthened, and uplift weapon, and those who awaited, make a vengeance on them. It should be done one of another, and the fardhu kifayah responsibility excludes. This, is if they do not come to our country. "So if it comes to the Islamic state, then it becomes a fardhu ain for each and every one of the land that he entered, to the women and the people ..."

(Daud, n.d. \& Shaghir, 2009)

Another example is the book of Muniyyat al-Musalli, the work of Sheikh Daud al-Fathani, who has applied the doctrine of war and jihad even though the book originally contained a debate about prayer (solat). For example, the first chapter of the book, Sheikh Daud al-Fathani (2010) states that: "And it is required by solat al-wustha; the asar prayer. And the reason is determined by mentioning it because of the superiority and nobility over the other. And it is the reason for the verse to be revealed because it is affluent to pray when fear. That is, Muslims and the Prophets (peace be upon him) on the some of the war, the Prayer of the Messenger of Allah (pbuh) praying for the zohor on his customary path and is a musyrikun (idolaters) close to them, that they seen them as Muslim. Then when they are finished from the prayer, said half of the idolaters "If you gather at the same time when they are in their prayers, they will surely have you." Then the other half said that, they were then, this prayer is especially grateful to them from their fathers and from their children, which they want them to pray asar. Then, descended Gabriel a.s. on the Messenger of Allah (may peace be upon him) with prayers of syiddah al-khauf. Then, point out to you the greatness of asar prayer and the fact that all the idolaters knowing. " 
Although, in general, the discussion on the issue of prayer in a war situation, but the existence of a jihadist doctrine can be seen clearly. Some important essays can be explained from the quotes. It is, first of all, the importance of maintaining prayers even in war conditions. Thus, war can be among the reason for alternative acts of prayer practices (in vigilance), as well as informing the story and situation of war in the time of the Prophet.

\section{Works of Abdul Samad Palimbani}

Among his work is Nasihah Muslimin, written in Arabic, to be read by all Muslims of the world without enclosed to Muslims in the Malay world. Other reasons it was written in Arabic because they wanted to disassociate the Dutch, as they did not understand the Arabic language. It is an evident that this book is in Snouck Hurgronje's reserve. The main objective of this book is to raise the spirit of jihad against the Dutch colonization. It contains 7 articles in all (Julkarnain, 2016), where;

Chapter 1: Explanation of the priorities and orders of jihad. It divides into two, namely fardu ain when the enemy attacks the Islamic state, and fardu kifayah when the service is needed to help the Muslim brothers.

Chapter 2: Hadiths on the priorities of jihad. Among them is the tradition of jihad as the main practice, of more than 50 times pilgrimage.

Chapter 3: Preference for jihad preparation.

Chapter 4: Hadith on importance of infaq in the path of Allah and the preparation of war.

Chapter 5: Priorities of jihad preparations and archery training commands.

Chapter 6: The martyrdom priority. Among them is the tradition of rewards of jihad remains steady and hinder from the slander of the grave. The rewards of jihad at night are equal to 1000 fasting at nights and prayers.

Chapter 7: Some terms and conditions of jihad.

Chapter 8: Closing - the best time to perform jihad.

The book directly addresses physical warfare (Qital) against the Dutch. This jihad is required to maintain the survival, nation, dignity and position of Islam. It turns out that this book affects the jihad effort in the Malay world. For example, the Hikayat Perang Sabil in Aceh was influenced by this book. In terms of submissions and arguments, it provides 35 verses of the Quran that encourage jihad to Muslims. It explains who needs jihad; healthy men and believers. It uses 13 prophetic verses and some of the opinion of fuqaha and mufasirin that are muktabar. At the end of his book, he offered several prayers, amulets and self-help fortunes for the jihadists. He suggested to read the verse "laqaja akum" 10 times after performing prayer. The benefit is to avoid enemy disruptions and longevity.

\section{Sosio-Political Tactical Dimensions in Jihad}

Jawi scholar figures; Sheikh Ahmad Zain Patani and Abdul Samad Falimbani have channeled the support and spirit of jihad to the ruler of the Malay World. Sheikh Ahmad Zain Patani has a personal relationship with the ruler of the Malay World. In this regard some evidence may be given; 
First, in 1772, Syeikh Abdul Samad al-Falimbani acted to send two pilgrims to Sultan Hamengkubowono I and Susuhunan Prabu Laka. He also sent a letter of praise to the earlier jihad of King Mataram, calling for them to continue fighting and to fight against Drewes colonization.

Second, Sheikh Ahmad bin Muhammad Zain is a scholar who is in charge of maintaining good relations between the government and as the reference in the Malay world. Among them, include sultan in Pattani, Kelantan, Terengganu, Kedah, Johor, Riau-Lingga, Deli, Langkat, Pontianak and Sambas. For example, he had sent a letter containing prayers $\left(d o^{\prime} a\right)$ for the Sultan Mansur of Kelantan in 1891. In his letter, he had prayed that the state of Kelantan would be spared from the invasion and plagiarism of the infidels. Among the essence of prayer is the following (Hasanuddin, 2009):

"That You shall secure him (Sultan Mansur) and his country (Kelantan) and his people and all the Malay states and his kings from all their infidelities and deceit. And prohibits, my Lord from entering them, the infidels, to Kelantan and all the Malay states by ordering him command orders there ".

In the prayer contained the value of the struggle that Syeikh Ahmad Zain attempted in conjunction with Sultan Mansur's coronation in Kelantan. In addition, he also sent a letter dated 1323

Hijrah to Sultan Zainal Abidin III, Sultan of Terengganu, and be reminiscent to defend his homeland from colonialism.

"And it is extended by the time of your Majesty and your seed in a kingdom that does not interfere with the difficult and distressed by ajnib (foreigners)."

The letter is a proof that the Malay scholars in Mecca cares for the defense of Malaya. Therefore, they sent letters containing the value of the struggle to the sultan, to urge the jihad movement against the invaders, and to pray that God would protect the Malay Empire from falling into colonialism.

\section{Jihad of Ashab Jawi's Impact in Malaya Impact on Muslims}

Referring to the struggle of jihad in the Malay World, it is divided into two types;

1. Jihad dakwah and ta'lim. Jihad dakwah is a form of effort and sacrifice of scholars to spread the message of Islam to the whole community.

2. Jihad war is the true concept of jihad in the form of armed opposition against the infidels as practiced by scholars in the Malay World. Among them are Syeikh Daud al-Fathani, Nawawi alBantani, Yusuf Makassar, Abdul Samad al-Falimbani, and Tok Janggut.

The struggle against colonists in other words, national patriotism has begun since the early 19th century. The patriotism movement that took place in Malaya was at the district and state level. It took place from the Portuguese invasion of Melaka in 1511 AD, the Netherlands in 1641, and the British in the 19th century. The British intervention in Malaya marked on the beginning of the Pangkor Agreement (Perjanjian Pangkor) in 1874 (Latif, 2001). 
In the historical frame, it was recorded that the British had attempted to enter Pahang in 1885, through the efforts of Fank Swettenham (who had been pronounced by Governor Smith), but failed. During 1886, Governor Fred A. Weld had also come to see the Sultan to favor an agreement with the British. However, the business did not work. Indeed, the British never gave up, until 1887, Hugh Clifford had come with the intervention of the Johor Government which caused Sultan Ahmad to enter into an agreement with the British (Linehan, 1936).

This agreement, nonetheless Sultan Ahmad was not pleased with, as well as the Pahang officials. That is, then has created series of opposition to the British in Pahang. The beginning of the war which marked the hostility and opposition to the invaders was from 1891 to 1895 in Lubuk Terua (Gin, 2009). The war, also known as the Bahaman War, was the starting point for the rise of the Pahang Malay fighters against the invaders and their agenda (Roselan, 1998).

\section{Chronology of Bahaman's Resistance in Pahang}

There are some chronology of Dato Bahaman's opposition;

1. In October 1881, the Pahang Great Britain agreement was signed and Hugh Clifford came to Pahang, holding the post of British Agent. This was followed in October 1888, J.P. Rodger was appointed as the first British Pahang Resident. The new administration was formed in Pahang. Pahang was divided into several districts and placed under the Tax Collector under a European Magistrate. Kuantan is under the administration of A.H. Wall, Pekan by F. Belfield; Kuala Pahang by W.W. Michell; Temerloh by E.A. Wise; Hulu Pahang by W.E. Michell and Hugh Clifford as Hulu Pahang enforcer (Muttalib, 1972).

2. The new policy has deprived the role of local authorities as tax collectors in their respective constituencies. In lieu of the loss of the power, the British proposed the payment of allowances to the governors. It involves Tok Gajah, Temenggung, Shahbandar, Maharaja Perba Jelai, Orang Kaya Chenor and Orang Kaya Temerloh and Dato 'Bahaman. This annual allowance bid was opposed by Pahang officials, however Rodger's Resident warned to take legal action against those who deny the British decision (Linebah, 1973 \& Gopinath, 1991).

3. In 1894, Dato Bahaman launched an attack on the police station in Lubuh Terua. It was because of 3 followers of Dato Bahaman being detained by C.E.B. Desborough on charges of collecting forest products without permission. After dismissing Dato Bahaman's application of them being released, Dato Bahaman began to open publicly. The movement led by Dato 'Bahaman was supported by Tuk Gajah (Imam Perang Rasul) and Mat Kilau. His followers are increased to 600 people and assisted by 100 Orang Asli.

4. Then, Dato Bahaman, Tok Gajah (Imam Perang Rasul) and Mat Kilau retreated to Kelantan and Terengganu. In Terengganu, Malay fighters were accepted and instilled in the spirit of jihad by Tokku Paloh (Sayyid Abdul Rahman al-Idrus).

5. At the end of 1894, Dato Bahaman with Mat Kilau, Teh Ibrahim and Awang Nong launched an attack on Kuala Tembeling and successfully captured Jeram Ampai fortress. However, this success did not last, as the British team succeeded in resigning them. Once again, they enter the border of Kelantan and Terengganu. The tracking movements of Pahang fighters were carried out by British 
INTERNATIONAL JOURNAL OF ACADEMIC RESEARCH IN BUSINESS AND SOCIAL SCIENCES Vol. 9, No. 7, July, 2019, E-ISSN: 2222-6990 @ 2019 HRMARS

troops under Hugh Clifford to Kelantan and Terengganu, but failed because they did not get cooperation from locals (Clifford, 1961).

From this series of events, we find some of the key points: First, this struggle is triggered by the spirit of jihad, as well as unsatisfactory with the forced change brought by the British. Moreover, the British forced the king and the Malay emperor without conscious to the Malay culture. In fact, this opposition is also endorsed by the Malay ruler himself.

Second, it gets the majority of the Malay community, especially the clerics. The scholar is indeed a place of reconciliation and the spirit of Jihad. This is well understood by the British itself. The Pahang fighter had a relationship with a scholar in Terengganu, Tok Ku Paloh. Tok Ku Paloh among the people who blew and driven the spirit of jihad in the fighters of Pahang. Along with the spirit of jihad, Dato 'Bahaman (along with Tok Janggut and Mat Kilau) attacked the British fort in Kuala Tembeling and subsequently captured Jeram Ampai (Zakari, 2012).

Basically, the spirit of jihad in Pahang is extensive. As mentioned, Uthman Senik is a silat (a martial art) teacher of Pahang fighters such as Mat Kilau, Dato 'Bahaman, Tok Gajah, Mat Lela and Panglima Muda Jempol. Uthman Senik is actually a pupil of Syeikh Abd Qadir Tok Bendang Daya who is a wellknown scholar in Patani. He studied thoroughly with Tok Bendang Daya (Taib, 2001). Therefore, it is clear that the forces against the colonists in Pahang have a network of doctrines of jihad scholars from Patani (Ismail, 2015). Besides Uthman Senik, another scholar, who teach and preach on Pulau Tawar is said to inject the jihad spirit to the fighters in Pahang namely, Tuan Haji Ishak (Ismail et.al., 2014).

Third, there is a defector element that supports the British in order to obtain temporary power. When these Malay warriors with their families fled to Terengganu in late 1892, as the British raised their military numbers, there were two Malay leaders who were British supporters; Toh Raja Jelai and Panglima Garang Yusof. Both of them with their followers were involved in the British raid, seized the Jeram Ampai fortress on June 25, 1894.

Fourth, it is strategically prepared. Among them (Chandran, 1972),

1. Intelligence techniques, before the action and attacks are committed to the British.

2. Prevarication technique, to deflect British attack in their operation in Jeram Ampai fortress. Dato Bahaman has used three road guides in the forest to R.W. Duff. Duff was supposed to bring 78 British militants attacking Jeram Ampai fortress on June 25, 1894 had failed to do so. This causes R.W. Duff and Sikh soldiers failed to help Jeram Ampai's fortress along with Lyons captain and Walker captain, as planned earlier by the British.

3. Reach the forest as a place of war because the British army and the Sikh soldiers have no experience in guerrilla warfare in the forest. This is evident when the Sikh soldiers in Captain Wise team became foul when attacked by Malay warriors. They have been shot down by their own armies, causing the Wise captain and several others to be killed. The Malay Warrior also made the forest a hiding place and fled.

4. Initial inventory tactics to escape if there is any problem. They have ready to get first aid logistics before and after the war. They have been hiding to gather and gain support from the community. 
All of these tactics led the British to spend big money and an extensive time to eliminate this opposition. The colonial opposition in Pahang is in fact the struggle to defend religion, homeland and Malay dignity (Ali, 2008). This is because, warriors who fight the colonialists know their true purpose is to come to the Malay world to spread the Christian faith, to harvest the produce and to spread their power and strength. The historians define the purpose of the colonialists to the Malay World as $3 G$ namely, God or Gospel, Glory and Gold (Tjandrasasmita, 2009). The statement was actually supported by the statement that Mat Kilau's grandfather had described in his struggle against the British as follows; Mat Kilau answered, white people wanted to spread Christianity, probably because fear of Islam was grew stronger in Asia, especially in Kelantan and Acheh, being nicknamed as Serambi Mecca.

Mat Kilau is aware, that the British as well as wishes to colonize them, they also want to spread the Christian teachings, rather than the earlier intention of running spice trade and tin ore. The fact is that Mat Kilau is very much in line with the main purpose of jihad. Allah insists that jihad is to uphold the rules of Allah on earth, revealing His religion of Islam (Salih, 2009). Hence, any threat to Islam's diligence and its followers, jihad will be declared against the threat as has happened in the state of Pahang.

Pahang fighter also has a close association with Kelantan and Terengganu states. Dato 'Bahaman, Tok Gajah and Mat Kilau are said to be retreating and hiding in the two states when hunted by the British. This is due to the conviction and the existence of the inter-state network of Pahang with Kelantan and Terengganu, whereas as it is known that the struggle against the colonialists in the two states is raised by the clergy and enlivened with the spirit of jihad. Thus, the relationship between Pahang, Terengganu and Kelantan is not only from the intellectual point of view but from the point of struggle and jihad (Mohd Nor, 2011).

\section{Impacts to British and Dutch Colonization}

British colonialists are aware of the influence of regional and international jihad networks in Pahang. Examples can be seen from R.A. Blasdell's researches from London Missionary Society. It examines the practices and perceptions of Islam among the Malay community in the early 1940s, with the aim of finding space for the spread of Christianity. In his observation, Blasdell found a Malay student who went on pilgrimage to Makkah, stayed there for several years and became a scholar, when returning to Malaya would set up an institution of study to enhance the understanding of Islam in society. It includes driving the jihadist spirit against British colonists among its students (Blasdell, 1945).

This historical fact has directly been the basis that motivates the opposition of the Malays against colonialists in Malaya and Pahang. In the history of Malaya which was constructed by colonial scholars, it was highlighted that the struggle of the Malay Pahang was isolated, alone and founded upon self-interest. They denied that it was founded on the spirit of jihad. In fact, they try to sink the greatness of Islam in the past that can inspire the spirit of Islam. On the contrary, they have highlighted themselves as the bearers of civilian to the Malay community (Rahim, 2012). 


\section{What Affects the Colonizer Policy in Malaya}

The British in the colonial era understood the role of Jihad brought by Ashab Jawi. They have run some of main policies. It is in the form of efforts to restrict the potential of Islam and Islamic learning institutions in society. This is because they know the potential of Islam (categorized as Islamic politics) (Haniff, 2007) which endangers the British colonialism in Malaya. British power has a special policy of Islam in Malay society. This is based on a few key reasons:

\section{An Awareness on the Risk of Islam as a Struggle Factor against the Invaders.}

In the colonial effort to study all the structural aspects of the Malay community, they acknowledge that Islam and Islamic literacy are the basis of Malay identity strength. For the British and Dutch, Islam is a poison that needs to be monitored. Nevertheless, this cannot be done outright because of inviting the resistance of the Malays. Some examples may be given, among others;

1. R.J. Wilkinson and Winstedt in Malay school planning have removed the subject of Islamic history from the content of the Malay school syllabus (Arba'iyyah, 2001). It is realized that it will raise awareness of the greatness of Islam over the world in the past (Ozay, 2011).

2. The British and Dutch colonizers suspect the Hajj and scholarly institutions which are regarded as the bearers of problems that would suppress the colonial power (Al-Junied, 2005). They regard the Hajj institutions as a center of awareness of Islam against western colonists. On that basis, they take the basis of restricting or crushing the Malay community's pilgrimage program.

3. British and Dutch masters who are the major figures in developing colonial knowledge are comprised of western IPT graduates who are exposed to orientalism movement. So, they understand that the trauma of the Crusades has caused Muslims to be hostile to the western powers. Wilkinson in his compilations of his study of the Malay community, as the main text for the colonial cadet training, asserted the dangers of Islam for the British power (Wilkinson, 1906). So is in the case with Snouck Hurgonje. Prior to being appointed as a Dutch advisor, he had conducted a thesis on Hajj in the Middle East. After all, British and Dutch masters (though hostile) are interconnected in handling Islam in their respective colonies (Schauer, 2012).

\section{Colonialists and efforts to undermine the potential of Islam in Malaya.}

The British are aware of the contribution of Islamic educational institutions in bringing awareness to society. It also founded the Islamic political system with the formation of various Malay-Islamic governments. In fact, they are puzzled to understand how Islamization is in a safe form has been able to change the world-view and become a substance element in the Malay community. This was confirmed by John Taylor that if the British did not come to Malaya it was certain that Islamic law would be the Law of The Land of Malaya. The result is, they understand that this Islamic transformation can be made with the existence of a sophisticated educational system and able to answer the most important issues of society. Therefore, they use hegemony tactics by spreading in the community that the Islamic education system is not viable. This is supported by the later British education policy.

This western education system is characterized by several forms (Yao, 2009); 
1. Unfair. Because it is different for the Malay community. Only the king's son and the Malay emperor are given good education in terms of teachers and facilities. This is not given to subordinate Malay society.

2. The goal of education. For young governor, they are planned to become a mid-job force in MAS. For subordinates, they are expected to continue to be subordinate classes, as fewer farmers than their families. They also require the workforce for low-ranking as a carriage driver and an office boy.

3. The content of educational system that does not help the social mobility process of society. More importantly, it does not help to form active and critical thinking (Adnan, 1998). For the prince's class, they were taught the subject of glorifying power and the British value system. For their subordinates, they are taught with ordinary subjects (reading, writing, calculating and regular technical skills) (Khairi, Ramli \& Ismail, 2012).

British schools are being proclaimed in society as the best. British graduate school graduation will get a certificate that allows them to get subordinates in MAS. This clearly causes any educational system out of the mainstream like the pondok system will not be recognized. Members of the Malay community began to be influenced by this phenomenon, as pondok graduates were not employed in British service (Yahya, 1985). Means, they successfully spread the secular ideology that denies the role of religion and considers the work of salary as a prestige. It is said that one's life is more secure when he gets a salary every month to fulfill his or her life (Rahman, 2000).

Although they claim to be the defenders of the Malay community, they are essentially more concerned about their investment profits without regard to the welfare of subordinates or foreign immigrants. Historical facts prove the living conditions of Chinese and Indian immigrant workers working in fields and mines are very frustrating (Sua, 2009).

In the history of the Malay World, it is admittedly, pondok clerics have never been directly opposed to the British, but the existence of both in a different paradigm is recognized by them. In many respects, the Islamic scholar's response to the hegemony of British colonization and education system was made in some form:

First, the pondok has become the last fortress of Muslims defending the Islamic faith rather than impregnated with the idea of colonial secularism. Even in many circumstances, the scholars have been directly involved in the invaders (Zakari, 2012). This can be seen from Tokku Paloh's efforts to support and give a jihad spirit to the struggle of Dato' Bahaman (Ismail et al., 2014). In fact, in a more proactive form, Tokku Paloh has played a role in blocking the threat of British intervention in Terengganu. In this regard, Tokku Paloh has practiced strategic thinking methods by incorporating clause 14 in the Itqan Muluk Constitution;

"There is no passage, and no law shall at all times, make a treaty or endeavor to release or surrender the state and its kingdom, or a part of its power or tenacious (Huquq) to any government, or to the powers of the European or other. So, if the king goes through this prohibition and defamation, it is deemed that he will break the trust that responsible upon him, and there is no such legal act. So, when 
INTERNATIONAL JOURNAL OF ACADEMIC RESEARCH IN BUSINESS AND SOCIAL SCIENCES Vol. 9, No. 7, July, 2019, E-ISSN: 2222-6990 @ 2019 HRMARS

it is not obligatory upon the members of the kingdom and all the people to be loyal to him, he then must have been brought down from his kingdom and appointed him a new successor. "

This clause 14, explicitly stipulates that the king's unauthorized acceptance of federation with the authority of the infidels. This is true, because the 14th clause has complicated the work of Harold Mac Michael to persuade the Terengganu sultans to sign an agreement on the establishment of the Malayan Union, which means the state's surrender to British colonialists (Abdul Wahid, 1992).

Second, the work of the Malay scholar on the topic of jihad and political doctrine was adopted in the Malay learning system. It means, in Malay pondok study system, the issue of jihad is one of the most important topics that Muslims need to learn. Hence, it is said that jihad doctrine is also in line with the process of Islamization of the Malay World.

Third, scholars respond proactively to British education programs. For the state constitution of Kelantan, this has been done by Islamic educational scholars. This is evident from the study of Dr Nur Azuki Yussuf who found Islamic education administrators in Kelantan to reform in the form of better systems, curriculum and structure improvement. This has proven to have led religious schools in Kelantan to move forward and become the choice of the Malay family. He pointed out: "The British administration and management pattern is really testing the flow of Islamic development in Kelantan. Thus, there has been a high awareness of the Kelantan community to strengthen Islamic educational systems and institutions in order to compete with conventional sponsors sponsored by the colonialists "(Azuki, 2007).

In other words, confronted with the British policy of trying to marginalize the Islamic education system, the Kelantan clerics did not take passive attitude, but moved actively to study, imitate and reform the Islamic education system without sacrificing true Islamic values. The most important goal is to ensure the education system remains relevant in Kelantan Malay society despite having to deal with various modernization threats. This way indirectly, according to Dr Abdullah Ishak, the Kelantan Malay cleric has been the main guide for community activity towards Islamic values and being a refuge and fortress to counteract the assault on the secularism-based modernization idea brought on by western colonists (Abdullah, 1995).

In post-independence development, scholars have been seen to have proactive, selective and strategic modernization program of education system. They have not neglected the mainstream education system negatively, but have sent their children into this mainstream education system. They understand the benefits of dual-system knowledge (pondok education and national schools) which will strengthen the formation of human capital in Malaysia. As a result, we find that many of the children of the pondok teachers have succeeded in holding various top positions in the State. Many of them have become academic staff in various fields in Malaysian IPTA. 
INTERNATIONAL JOURNAL OF ACADEMIC RESEARCH IN BUSINESS AND SOCIAL SCIENCES

Vol. 9, No. 7, July, 2019, E-ISSN: 2222-6990 @ 2019 HRMARS

\section{Conclusion}

As conclusion, the resurgence against the colonialist who drives the spirit of Islamic Malay nationalism has been played by past scholars, especially Ashab Jawi. Historical facts have proved despite their role is often drowned by British-sponsored history. They highlighted the feudal Malays as the earliest independence fighters. This fabricated view must be rectified in order to create the truth and show the dimensions of the jihad of the Malay scholar characterized by the religious spirit that will achieve the reward of the shuhadah by Allah.

Muslim scholars like Sheikh Muhammad al-Falimbani, Sheikh Muhammad Zain al-Ashi, Sheikh Muhammad al-Fathani, Dato Bahaman, Tuk Gajah, Mat Kilau and other warriors have urgently dispersed the element of jihad till the last i.e. pondok educational system. It is to ensure Islamic teaching continuously practices in Malaya. The feudal authority, however, defending thru the concept of nationalism which is unfamiliar in the formal educational system where Muslim privileges are not at a stake.

Pondok is the crux of the Islamic education system in the Malay world. In the present day, improvements have been applied in the educational system where pondok integrating with the modern educational system in order to challenge the new world, to maintain the legacy as well as the roles of pondok as well as their scholars.

\section{Acknowledgement}

This research has been made possible with the funding from Ministry of Higher Education Malaysia (MOHE) under research grant FRGS FP031-2016, "The Construction of Wasatiyyah Model in Addressing Symptoms of Religious Extremism in Malaysia"

\section{References}

Abdullah, I. (1995). Pendidikan Islam dan Pengaruhnya di Malaysia. Kuala Lumpur: DBP. Abdullah, M. (1981). Kisah Pelayaran Abdullah ke Kelantan dan Judah. Kuala Lumpur: Fajar Bakti. Adnan, H. N. (1998). Za'ba dan Melayu. Kuala Lumpur.

Ali, S. H. (2008). The Malays Their Problems and Future. Kuala Lumpur: The Other Press.

Amirul, H. (1992). Aceh and the Portuguese: A Study of the Struggle of Islam in South East Asia 15001579. Disertasi Sarjana. Institute of Islamic Studies, McGill University, Montreal, Canada.

Amirul, H. (2004). Islam and State in Sumatera: A Study of Seventeenth Aceh. Leiden: E.J.Brill.

Arba'iyah, M. N. (2001). Pensejarahan di dalam Tradisi Barat dan Melayu: Satu Perbandingan Ringkas. DIm. Redzuan Othman (ed.). Jendela Masa. Kuala Lumpur: Penerbit UM, 26-27.

Azra, A. (2004). Jaringan Ulama Timur Tengah dengan Kepulauan Nusantara Abad XVII dan XVIII. Edisi Revisi. Jakarta: Prenada Media.

Azra, A. (2015). The Significance of Southeast Asia (The Jawah World) for Global Islamic Studies: Historical and Comparative Perspectives. Kyoto Bulletin of Islamic Area Studies, 8, 69-87.

Azuki, Y. N. (2007). Institusi Dan Sistem Pendidikan Islam: Suatu Analisa Tahap Perkembangannya di Kelantan. Jurnal Al- Tamaddun, 2, 139 - 160.

Blasdell, R. A. (1945). Islam in Malaya. International Review of Missions, XXXIV, 169. 
INTERNATIONAL JOURNAL OF ACADEMIC RESEARCH IN BUSINESS AND SOCIAL SCIENCES

Vol. 9, No. 7, July, 2019, E-ISSN: 2222-6990 @ 2019 HRMARS

Boxer, C. R. (1969). A Note on Portuguese Reactions to the Revival of the Red Sea Spice Trade and the Rise of Atjeh, 1540-1600. Journal of Southeast Asian History, 10 (3), 424.

Braddel, T. (1851). On The History of Achene. The Journal of the Indian Archipelago and Eastern Asia, $5(2), 18$.

Bruinessen, M. V. (1992). Tarekat dan Politik: Amalan untuk Dunia atau Akherat. Pesantren, IX (1), 314.

Chandran, J. (1972). The Pahang Expedition 1894. In. Malayan Police Magazine. Kuala Lumpur, 1 (7), 240-245.

Clifford, H. (1961). Expedition toTrengganu and Kelantan. Journal of the Malaysian Branch of Asian Studies, $34(\mathrm{IH}), 1-62$.

Darusman, L. H. (2008). Jihad in Two Faces of Shariah: Sufism and Islamic Jurisprudence (Fiqh) and the Revival of Islamic Movements in the Malay World. (Doctoral dissertation). Australian National University, Australia.

Farooqi, N. R. (1986). Mughal-Ottoman Relations: A Study of Political and Diplomatic Relations Between Mughal India and Ottoman Empire, 1556-1748. (Doctoral dissertation). University of Wisconsin, Madison.

Ferguson, R. J. (2008). Contemporary Political Mobilisation of the Caliphate: The Clash of Propaganda and Discontent. The Bulletin of the Centre For East-West Cultural and Economic Studies, 8 (1), 1-27.

Gin, O. K. (2009). Historical Dictionary of Malaysia. UK: Scarecrow Press.

Gopinath, A. (1991). Pahang 1880-1933: A Political History. Kuala Lumpur: Malaysian Branch of the Royal Asiatic Society.

Hasanudin, D. (2009). Islam dan Politik: Dinamika Kerjasama Tokoh Serumpun dalam Menghadapi Penjajah. Kertas kerja dalam Dialog Membangkitkan Memori Kolektif Kesejarahan IndonesiaMalaysia. Tanjung Pinang, Indonesia. 7-9 Oktober 2009.

Hassan, M. H. (2007). Explaining Islam's Special Position and The Politic of Islam in Malaysia, The Muslim World, 97, 287-296.

Hassan, M. H. (2014). Islamic Legal Thought and Practices of Seventeenth Century Aceh: Treating the Other (Doctoral dissertation) Mcgill University, Canada.

Hassan, M. T. (2001). Tokoh-Tokoh Ulama di Negeri Pahang Darul Makmur. In. Zainuddin Haji Jumaat et.al (Ed.). Pahang Meniti Zaman. Pahang: Persatuan Sejarah Malaysia, 126-161.

Hurgronje, S. (1985). Aceh di Mata Kolonialis. Terjemahan Ng Singarimbun Daripada Buku the Achenese. Jakarta: Yayasan Soko Guru.

Hurgronje, S. (1994). Nasehat-Nasehat C. Snouck Hurgronje Semasa Kepegawaiannya Kepada Pemerintah Hindia Belanda; 1889-1936. Jakarta: INIS.

Ishak, A. M. (2000). The Malays in the Middle East. Kuala Lumpur.

Ismail, A. S. (2011). Persepsi Kalimah Jihad menurut Pandangan Ulama Nusantara. Prosiding Nadwah Ulama Nusantara (NUN) IV: Ulama Pemacu Transformasi Negara, 86-90.

Ismail, M. R. (2015). Kerdipan Bintang Melayu di Bumi Turki. Selangor: Karangkraf.

Itzkowitz, N. (1972). Ottoman Empire and Islamic Tradition. New York: Alfred A. Knof.

Jajat, B. (2014). The Dutch Colonial Policy on Islam: Reading the Intellectual Journey of Snouck Hurgronje. Al-Jami'ah: Journal of Islamic Studies, 52 (1), 25-58. 
INTERNATIONAL JOURNAL OF ACADEMIC RESEARCH IN BUSINESS AND SOCIAL SCIENCES

Vol. 9, No. 7, July, 2019, E-ISSN: 2222-6990 @ 2019 HRMARS

Junied, S. M. K. (2005). Western Images of Meccan Pilgrims in the Dutch East Indies, 1800-1900. SARI, 23, 105-122.

Kamaruddin, J. (2000). Dr. Burhanuddin Al-Helmy; Pemikiran dan Perjuangan. Kuala Lumpur: IKDAS.

Khairi, A., Ramli, S. \& Ismail, A. (2012). Kurikulum Pelajaran Vernakular Melayu di Tanah Melayu Pada Zaman Kolonial British Sehingga Perang Dunia Kedua. MANU. Bil. 18, 1-31.

Latif, A. B. (2001). Gerakan Kebangsaan di Negeri Pahang Sebelum Merdeka. In. Zainuddin Haji Jumaat et.al (Ed.). Pahang Meniti Zaman. Pahang: Persatuan Sejarah Malaysia.

Linehan, W. (1973). A History of Pahang. Kuala Lumpur: Malaysian Branch of the Royal Asiatic Society.

Dien, M. (2012). Knitting Togetherness among the Allied Malay: Aceh-Minangkabau-The Malay Peninsula. Tawarikh: International Journal For Historical Studies, 4 (1),1-17.

Marsden, W. (1783). The History of Sumatera. London: Thomas Paine \& Sons.

Mitrasing, I. S. (2011). The Age of Aceh and the Evolution of Kingship 1599-1641. Tesis Ph.D Untuk University of Leiden.

Nor, M. R. (2011). Keterlibatan Ulama' dalam Perjuangan Kemerdekaan di Terengganu. In. Azmul Fahimi et al. (Ed.). Prosiding Nadwah Ulama Nusantara (NUN) IV. Bangi: UKM, 300-304.

Muhammad, J. (2016). Resolusi Jihad Muslim Nusantara Abad XVIII; Interpretasi Jihad Abdul AlSamad Al-Falimbani. Tajdid, XV (1), 41-67.

Muttalib, J. A. (1972). Pemberontakan Pahang 1891-1895. Kota Bahru: Pustaka Aman Press.

Noriah, S. (1974). Orang Kaya Bahaman Satu Kajian Riwayat Hidup. Kajian Ilmiah. Jabatan Sejarah, Universiti Malaya. Kuala Lumpur.

Ozay, M. (2011). A Revisiting Cultural Transformation: Education System in Malaya during the Colonial Era. World Journal of Islamic History and Civilization, 1 (1), 37-48.

Ozay, M. (2011). The Sultanate of Aceh Darussalam as a Constructive Power. International Journal of Humanities and Social Science, 1 (11), 274-283.

Ozay, M. (2013). Preliminary Thoughts upon the Policies of the Ottoman State in the 16-Century Indian Ocean. World Journal of Islamic History and Civilization, 3 (1), 9-20.

Peacock, C.S. (2015). The Economic Relationship between the Ottoman Empire and Southeast Asia in the Seventeenth Century. Proceedings of the British Academy; From Anatolia to Aceh, Ottoman, Turks and Southeast Asia. Oxford: Oxford University Press, 63-87.

Rahman, A. A. (2000). Pekerjaan dalam Kehidupan Manusia. Petaling Jaya: Pearson Education Malaysia.

Reid, A. (1969). The Contest for North Sumatera, Atjeh, the Netherlands and Britain, 1858-1898. Kuala Lumpur: University Malaya Press.

Reid, A. (1990). An Age of Commerce in Southeast Asian History. Modern Asian Studies, 24, 5.

Reid, A. (2004). An Indonesian Frontier: Acehnese and Others Histories of Sumatera. Singapore: University of Singapore Press.

Restu, G. (1999). Ternate Sebagai Bandar Jalur Sutra, Jakarta: Ilham Bangun Karya.

Roselan, A. M. (1998). Kesan Sejarah dan Tempat-Tempat Menarik Pahang. Petaling Jaya: Oscar Book. Rozali, E.A. (2012). Sayid Muhammad Al-Saqoff in Johore-Ottoman Sovereign Relation. Advances in Natural and Applied Sciences, 6 (6), 893-897.

Rozali, E. A. (2014). Aceh-Ottoman Relation in Bustan A-Salatin. Mediterranean Journal of Social Science, 5 (29), 93-99. 
INTERNATIONAL JOURNAL OF ACADEMIC RESEARCH IN BUSINESS AND SOCIAL SCIENCES

Vol. 9, No. 7, July, 2019, E-ISSN: 2222-6990 @ 2019 HRMARS

Saim, K. (2011). Islamization of the Southeast Asia: The Role Of Turks. Dalam. Ottoman Connections to the Malay World: Islam, Law and Society. Kuala Lumpur: Islamic Book Trust, 1-31.

Saleh, F. (Sosiologi Sosiologi. (terj. Mohd Fauzi Yaacob). Kuala Lumpur: ITNMB.

Salih, F. (2009). Al-Jihad Dawabituhu WA Ahkamuhu. Al-Riyad: Dar Kunuz Isybiliya.

Samsudin, M.A., Yahya, M.Z. (2011). Pemikiran Usul Fikah Syeikh Ahmad al-Fatani dalam Kitab alFatawa al-Fataniyyah. Jurnal Melayu, 7, 173-92.

Saref, M. \& Faisal, A.H. (2014). Sheikh Daud bin Abdullah al-Fatani: Sumbangannya dalam Pendidikan Islam di Pattani. Jurnal al-Muqaddimmah, 2 (2), 102-14.

Schauer, M. (2012). Custodians of Malay Heritage: Anthropology, Education, and Imperialism in British Malaya and the Netherlands Indies 1890-1939. Tesis Ph.D untuk University of Pennsylvania.

Shaharil, T. (1997). The Asiatic Archipelago: History beyond Boundaries. JATI, 3, 132-135.

Smith, V. (1958). The Oxford History of India. Oxford.

Smith, W. G. C. (2007). Enunuchs and Concubines in the History of Islamic Southeast Asia. Manusya: Journal of Humanities, SI (14).

Sua, T. Y. (2009). The British Educational Policy for the Indigenous Community In Malaya: Dualistic Structure, Colonial Interests And Malay Radicaal Nationalism. CenPRIS Working Paper No. USM, 103/ 09 June 2009, 1-16.

Tahtooh, H. A. (1987). Commercial Relations between the Arab World and India (3th And $4^{\text {th }} / 9^{\text {th }}$ And $10^{\text {th }}$ Centuries) (Doctoral dissertation). University Of St. Andrews, Scotland.

Tisdall, C. (1916). Ideas of Mohammedan Malaya. The Missionary Review of The World, XXXIV, 348349.

Tjandrasasmita, U. (2009). Arkeologi Islam Nusantara. Jakarta: Gramedia.

Wilkinson, R. J. (1906). Malay Beliefs. Leiden: E.J. Brill.

Wahid, A. Z. A. (1992). Penubuhan Kongres Melayu Se-Malaya dan Kelahiran UMNO. DIm. Zainal Abidin Abdul Wahid et. al. Malaysia: Warisan dan Perkembangan. Kuala Lumpur : DBP, 193195.

Yahya, W.A. (1985). The Early Development of Islamic Education in Kelantan. ISLAMIKA, 111, 221222.

Zakari, A. G. (2012). Persekutuan Tanah Melayu Merdeka, 31 Ogos 1957: Liku dan Jejak Perjuangan Patriot dan Nasionalis Menentang British. Malaysia dari Segi Sejarah, 40.

\section{Corresponding Author:}

Muhd Imran Abd Razak

Email: imranrazak@uitm.edu.my 